\title{
School-context videos in Janus-faced online publicity: Learner-generated digital video production going online
}

\begin{abstract}
This article reports a case study on $s$ ChOOLtv, an online television for primary and secondary schools that aims to bridge the media gap between in-school and out-of-school learning environments. Contrary to its creators' expectations, the number of published videos has not increased since its establishment. Furthermore, the videos were mostly produced by primary-level students; few videos were released by secondary-level students. The article describes online publishing of learnergenerated videos by exploring the views of the students, parents, teachers, and principals. Sixty-seven informants were interviewed, and video production activities and discussions in classrooms were observed. The article discusses the factors hindering adolescents from making and publishing videos. It suggests media encouragement practices to enhance publishing-oriented digital video production in schools.
\end{abstract}

Keywords: video production; online publishing; publicity; media encouragement; digital literacy; new literacies

\section{Introduction}

The media world is constantly changing. Until recent years, adolescents' media usage was characterized by consuming-oriented solitary use (Uusitalo, Vehmas, \& Kupiainen, 2011). However, today's youth are attracted by visual media, interaction, and 24/7 participation in media environments (Ito, 2010). Interactive technologies enable them to produce and publish online (Lenhart, 2012), i.e., to make content open to the public (Jenkins, Clinton, Purushatma, Robinson, \& Weigel, 2006). Online content is becoming increasingly multimodal. Among Finnish 10-12-year-olds, for example, those who publish self-made videos are as many as those who post written texts in their leisure time (Suoninen, 2013).

Having adopted the role of content creator in out-of-school contexts, many adolescents desire to use their skills in school as well. But in Finland, many teachers have been reluctant to include new media and content creation in the classroom curriculum (Luukka et al., 2008; Pohjola \& Johnson, 2009). Although the number of teachers enthusiastic to employ the production of media content such as digital stories and videos in diverse educational settings has recently increased (e.g., Butler, Leahy, 
\& McCormack, 2010; Hobbs, Jaszi, \& Aufderheide, 2009; Kearney, 2009), school-driven products are rarely published in environments with unlimited access (Kupiainen, 2013a).

As evolving digital technologies enable publishing activities in schools, the choice of publishing needs to be considered as part of content production and media education or literacies. This article, reporting an explorative case study on the online television sChOOLtv (a pseudonym), contributes to the relatively under-researched field of online publishing. This area requires further examination to understand the schools' relationship with publicity and online presence related to school activities. The article concerns not only adolescents, but also primary students who have been neglected in this field.

Before presenting the empirical part of the study, the article will discuss the role of publishing in the school-based production process by introducing the concepts online publicity and media encouragement (Jaakkola, 2010) to approach media education from the perspective of production. These are considered the key concepts for creating pedagogical thinking in terms of online publishing. Additionally, sChOOLtv is presented as a new literacies practice.

\section{The relationship between the school and publicity}

Since media education is conducted from the perspective of reception and consumption, the relationship between the school and publicity remains a diversely developed area. Dealing with the public is increasingly important among young adolescents, who gain visibility by publishing and sharing in the networked public and thus attain reputation, validation, and recognition among peers (Lange \& Ito, 2010). Consequently, online presence and publicity need to be discussed within media education. However, Jaakkola (2010) considers the gap between generations problematic, as educators and adolescents live in environments with different thinking and operation models. Thus, the interface for a constructive educational dialogue is limited, since the educators, unfamiliar with the environments where adolescents spend time, cannot understand what can be done there.

Online practices, especially among young people, challenge the dichotomy of the private and the public — labeled one of the "grand dichotomies" in our social world (Bobbio, 1989) — and blur the boundaries between the two (Kupiainen, 2013a). Discussing the concepts of public and private are beyond the focus of this article; however, to crystallize the concept of publicity in its traditional sense, it can be defined as the state of being public or open to general observation or recognition (Lehtonen, 2008). In contemporary networked platforms, publicity indicates online presence (Stern, 2008) and openness and promotion (Malin, 2011). It concerns communication and activity beyond the private zone, provoking indirect interaction with potentially far-reaching consequences (Jaakkola, 2010). 
In this study concerning the school's online publicity, publicity also refers to public visibility and accessibility in terms of the activity level and interaction among the school, homes, and society (Jaakkola, 2010; Nieminen, 2006). Defining "the public" as a kind of community, Boyd (2008) emphasized its networked nature and production and participation aspects. Social exchange, as described by Wittel (2011), is an essential feature of online publicity that is a reciprocal relation between users and networks that generate and share content with each other (John, 2012). Users are not mere passive receivers of the content created by others.

Learner-generated content such as videos produced by students becomes accessible to the public outside the school through online publishing. Students are also able to see media content made by other young people, thus benefiting from the open resources. In networked environments, however, the user can control the visibility of personal information to different target groups through privacy settings (Boyd, 2008). The situation is somewhat contradictory; whereas the recent rise of sharing, openness, and collaboration necessitates increasing publicity, current negative phenomena such as sexual or bullying messages (Livingstone, Haddon, Görzig, \& Ólafsson, 2011) emerging on the Internet make most adults concerned about children's online activities.

Until recently, media education has been mostly perceived as media protection aiming to restrict Internet use and teach children to protect themselves against harmful content (Buckingham, 2006). To address online presence and publicity in media education, Jaakkola (2010) suggested that media education should be accomplished from the perspective of production, a key component in new media education (Kafai \& Peppler, 2011). Jaakkola introduced the concept of media encouragement to discuss education in online publicity, referring to education in and about publicity via networked platforms. It concerns providing the youth with safe media environments to experience the publishing-oriented process, permitting trial and failure. Thus, adolescents encounter situations that may lead them to negotiate with their peers and educators on the media ground rules regarding what is allowed or encouraged on networked platforms (Tuominen \& Mustonen, 2007). They should learn to understand what it means to share ideas and self-generated content (Ito, 2010). These ideas offer a new dimension to media education.

\section{Culture of media encouragement}

Due to challenges in the modern information society, Kupiainen (2013b) recommended taking into account the production perspective and sociocultural practices in the classroom curriculum to enhance digital literacy practices. In educational settings, online activities have potential advantages. Publishing-oriented media production motivates learners to create content (Lange \& Ito, 2010) and 
improve the quality of products (Butler et al., 2010; Karchmer, 2008). Furthermore, online publishing may promote reflective online interactions (Kearney, 2009).

Employing the perspective of production rather than restrictive media consumption as the starting point, media encouragement and education in online publicity are needed. From the perspective of pedagogy, media encouragement can be defined as an activity that aims to promote students' willingness to unveil their media content to an authentic public, which would serve as a medium for education in online publicity (Jaakkola, 2010). This pedagogical thinking is supported by Laitinen (2007), who claimed that students can understand media by producing media content, scaffolded by a teacher. Adopting this thought and supported by Kupiainen (2013a), it can be argued that learners assimilate and construct the shared rules on online activity by producing, publishing, and sharing media content in authentic media environments, i.e. "going online" in guided practices. Young people want to understand media through their own experiences (Stern, 2008), but they cannot educate themselves on their own (Jaakkola, 2010). However, adults with their poor understanding of media environments and new modes of expression are incapable of guiding the youth (Jenkins et al., 2006). To create rules, they must get to know the media environment (Pohjola \& Johnson, 2009).

Accordingly, a balance between encouragement and protection should be negotiated between adolescents and educators inside and outside of school, since this issue now concerns the collective impact of growing environments, in other words, the school, homes, and non-formal education. The teacher has the central role of coordinating this dialogue. A relevant question is at what age students should be encouraged to go online and be educated in online publicity. Thus, it is of interest to learn how younger children are involved in online publishing.

\section{Integrating publicity, media education, and new literacies practices}

Production and creativity are gradually taking a more prominent role in the field of media education (Kupiainen, 2013b). Furthermore, digital video (DV) production has been acknowledged in terms of pedagogical value (Hakkarainen, 2007) and as a literacy practice (Bailey, 2009). Due to modern technology, making DVs is rather easy and inexpensive (Buckingham, Willett, \& Pini, 2011). Most children have a mobile device equipped with a video camera, and free editing software can be downloaded from the Internet.

Before discussing online publishing as a new literacies practice, it is worth noting that the concepts of digital and media literacy or media education, though implying slightly different meanings, are employed in diverse research traditions to refer to the same set of thinking and competencies. As the term media includes the new media with interactive and networking 
characteristics enabled by digital technologies (Ylä-Kotola \& Arai, 2000), media education aims at enhancing media or digital literacies. Although media (or digital) literacy involves the production of digital works (Buckingham, 2006), it has not traditionally addressed privacy management in the networked public (Kupiainen, 2013a). Still, an aspect emphasizing online safety has been included in digital literacy (Buckingham, 2006): basic technical skills are not enough, but it is crucial to learn how to protect oneself against harmful content. Whereas the restrictive approach to media education considers the learners as media consumers who need to protect themselves from potentially harmful effects (Potter, 2010), the empowerment approach (Hobbs, 2011) may enable them to counteract the risks. The latter relies on young people's capability of gaining online success (Lange \& Ito, 2010).

In Finland, the national core curriculum (National Board of Education, 2004) presents media and digital literacies as a cross-curricular theme at all school levels (Kupiainen, 2013b), as well as a broad notion of texts extending multimodality in the concept of literacy. These imply the broader meaning of literacy, defined as new literacies (Coiro, Knobel, Lankshear, \& Leu, 2008). Besides various multimodal texts beyond the traditional media literacy, the concept of new literacies refers to a media world consolidating production, participation, and nonprofessional expertise (Gee, 2010). These elements are also present in the idea of "sharism" described by Ackermann (2011) and in collaborative knowledge resources in social media (Hobbs \& Donnelly, 2011). The contemporary participatory culture implies a low threshold for civic engagement, as well as strong support for creating and sharing. In these networked environments, children need new forms of cultural and communicative competence (Buckingham, 2006).

Thus, to employ modern media in the classroom curriculum, a school-context online television, sChOOLtv, was established to enable publishing of learner-generated videos and digital stories (Palmgren-Neuvonen, Kumpulainen, \& Vehkaperä, 2011). sChOOLtv was created in 2010 by representatives from the university, the local media school, and the education office, as well as a few active teachers in a preceding pilot project that was part of the OPTEK research endeavor in Finland (Vahtivuori-Hänninen \& Kynäslahti, 2012). Among the creators, it was agreed that videos are uploaded on the channel by the teachers. sChOOLtv was designed to not only make the videos publicly available and provide the learners with an authentic audience, but also to serve as an open learning resource and inspire other students and teachers. It was expected to challenge schools to conduct activities involving the learners, their families, and peers, as well as the educators (school, parents and non-formal educators), with a multilateral negotiation on media ground rules (Jaakkola, 2010) in a guided and controlled learning environment (Laitinen, 2007). 
Nevertheless, a brief look at sChOOLtv revealed that over three years, the number of published videos had not increased as much as the creators had expected them to. Additionally, the published videos were mostly produced by primary-level students, whereas few videos produced by secondary-level students were released. This article discusses some issues that may help us understand these phenomena.

\section{Aim of study}

In educational contexts, creative media production, not to mention online publishing (Buckingham et al., 2011), has been neglected by researchers (Kafai \& Peppler, 2011). This case study aimed to examine what happened when primary and secondary schools were provided with an online television for publishing learner-generated videos. It aimed to understand the interrelations between pedagogy and publicity, as well as between the involved parties, based on the case of sChOOLtv, a YouTube channel for schools. The following questions were formulated:

1. What are the views of the educators (teachers, principals and parents) and students on online publishing of learner-generated videos?

2. What kinds of issues may hinder the online publishing of learner-generated videos?

3. How do teachers implement media encouragement?

\section{Method}

YouTube, which is free of charge and popular with young Internet users, was chosen for $s C h O O L t v$ because it is a technically easy way to make videos accessible outside the classroom. By the end of 2013, 120 videos from 11 schools had been published on the YouTube channel sChOOLtv.

Before the sChOOLtv activities (producing and publishing videos) started, the students participating in the video projects, as well as their parents, were asked for their permission to publish the students' media products on $s$ ChOOLtv, addressing both privacy and copyright issues. In Finland, where fair use does not apply, unlike in the United States (Hobbs \& Donnelly, 2011), the copyright confusion (Hobbs et al., 2009) hampers authentic school education. YouTube videos are prohibited in classrooms, and online material is rarely available for free use in media projects. Furthermore, it is prohibited to publish media products with copyrighted material or to publish products without the permission of the producer-or in the case of a minor, the parent (Toikkanen \& Oksanen, 2011). 
Four training sessions on DV movie making were organized for the teachers who were interested in utilizing publishing-oriented DV production in the classroom curriculum. The goal was to develop expertise and share ideas to employ DV production in a pedagogically reasonable way, as well as to negotiate the ground rules for publishing. The teacher network was intended to provide the participants with peer guidance and possibilities for pedagogical collaboration.

\section{Research process}

This case study aimed to understand the novel phenomenon of publishing-oriented video production by examining multiple cases in nine schools, both at the primary and secondary levels. Observations, interviews, and field notes were employed, which is typical for a case study (Yin, 2009). Figure 1 shows the intertwined, partly parallel phases of the data collection, conducted by the first author and a research assistant, and the number of the informants with different roles.

\section{[Insert Figure 1 here]}

Note. $N=$ number of participants; $F=$ female; $M=$ male

Figure 1. The intertwined phases of study planning and data collection; the informant list included

Each phase suggested a need for a new type of data. First, media production activities and educational discussions in classrooms were observed and documented in field notes. Second, the teacher training sessions with discussions were observed and video recorded. Third, semi-structured theme interviews were conducted with students, parents, media educators, teachers, and principals. The long-term process developed the study through the participation of important informants, literature reviews, and joint reflection among the researchers.

Interviewees representing different types of roles, as well as schools participating and not participating in $s C h O O L t v$ activities were recruited to expand the perspectives on online publishing. A principal of one of the participating schools, and teachers who attended the training sessions and published their students' videos on sChOOLtv were interviewed. A teacher and two principals who were known for their experience in DV production in education but did not participate in sChOOLtv activities were also recruited. All interviewed principals were from primary schools, because no secondary school principals volunteered. Students and parents were recruited for interviews by the teachers involved in the sChOOLtv network. The students were allowed to choose between a personal or group interview (2-4 persons), resulting in one personal and 13 group interviews. All parents had a university degree. The interview frame was tailored to the informants' roles and ages. 
The data were coded by the first author and the research assistant using QSR NVivo. The data analysis consisted of the following phases:

1. Brief descriptions of the video-recorded classroom activities and teacher training sessions were written based on notes.

2. The video-recorded interviews (40 hours) were transcribed verbatim.

3. The transcripts and descriptions of classroom observations were subjected to qualitative content analysis following the inductive tradition (Elo et al., 2014). Using phrases forming a meaning as the units of analysis, the analysis aimed at searching for differences and similarities (Glaser \& Strauss, 1967) in the data to find the sources of willingness or reluctance to publish videos.

4. Informed by the literature review, the analysis was deepened focusing on the elements of online publicity and media encouragement.

The results of open coding are shown in Table A1. As is typical for inductive research (Elo et al., 2014), the trustworthiness of the analysis was checked and verified by frequent data reviews and discussions among the authors and research assistant during data analysis (Elo et al., 2014). Resulting from these discussions, excerpts representing each NVivo node were chosen to illustrate the interpretation of the themes identified in the data. The second author also contributed to the theoretical framework and discussion, whereas the third author participated in the methodological choices and writing process. Consequently, data triangulation, methodological triangulation, and investigator triangulation were accomplished (Denzin, 1970/2009).

Although the main findings are based on the interviews, other data were also used to support the interview results. The type of data is noted if needed. The teachers' school level is not indicated to maintain confidentiality.

\section{Findings}

The study revealed that the publishing activities rested on a few experienced teachers. This finding is typical of contemporary media education that is often taken over by the enthusiasts, who can be regarded as innovators, as described in Rogers' (2003) diffusion theory. Opposing strategies are common in the early phase of adoption, where the use of a certain technology needs to be explicitly motivated and justified in a community before acceptance and integration in everyday practices (Rogers, 2003). The younger generation's attraction to the modern media has consistently 
caused trepidation among the elderly through the ages (Jaakkola, 2010). In this case study, the early phase concerned promoting the young students' online activities.

\section{Videos in Janus-faced online publicity}

As a background for their understanding of online publishing of learner-generated videos, the interviewed principals first discussed the school's relationship with online publicity. Online practices were associated with the ideology of openness and sharing, which were described as a modern and up-to-date policy that the school "couldn't afford to miss out on." Education was regarded as part of societal development rather than an insulated area in society. The issue of "being public" was made synonymous with "being publicly available." Public presentation, such as sharing school-driven videos on networked platforms, was connected to the school's organizational public relations (PR) and communication strategy and policy. Open communication with the home and the society was considered crucial as stated by Principal 1: "Our school actively informs [stakeholders] about our activities through our webpage. I compile a weekly online bulletin for the parents. This way, everybody's awareness - the parents' and the surrounding community's - has increased, and the school has become entirely public." Online media content was thought to convey an "active" and "positive" image of the school for parents and other people interested in its everyday activities and events, as well as learner-generated media products: "If I'm googling the name of our school, and a lot of appropriate stuff comes up, links and activities we're involved in... I must say I'm sort of proud of it! Yes, that's us!" (Principal 1)

The teachers reported DV production to improve the students' skills in collaborative design, multimodal expression and technology. The teachers and principals regarded online publishing of videos as increasingly important for the students. Publishing-oriented DV production was also thought to offer many benefits for all parties: shared DV production promoted a sense of community among the students, online publishing enabled families and friends to see the videos, and in joint international projects, the students were able to share the school's activities with the school partners through videos. Online videos made the school's processes accessible to a wider public, "not just those involved in the project," as stated by Interviewed Teacher 4. Thus, the activities enhanced the ideas of new literacies. Furthermore, seeing themselves in online videos was thought to raise students' self-esteem, as explained by Interviewed Teacher 3 who imitated a student: “@Hey, this is made by me and I've been involved!@”

Although some teachers reported great diversity in their colleagues' opinions on youth media culture, most had adapted to the presence of online media in their students' everyday lives: "The kids are in the media jungle where they can encounter all kinds of things, and we cannot inhibit it" 
(Interviewed Teacher 3). They argued that children could not be kept away from YouTube. Thus, the sChOOLtv teachers regarded education in online publicity as essential in the classroom curriculum.

The interviewed parents believed that their children would act appropriately in the networked media as they would in real life. They also expected the children, through guided online experiences, to learn what kind of information to release and what kind of image to construct on the Internet. Furthermore, the limits of privacy were speculated to be vanishing: "If you can find material on everybody on the Internet, is it, after all, so dangerous to find information about oneself there?" (Parent 1)

However, every coin has two sides. Principal 1 claimed that the publicity policy has varied broadly over the past decades. Before the rise of the Internet, information released by schools was scarce. But in the late 1990s and early 2000s, the trend was to reveal photos and information on the students and their activities rather openly. Principal 2 explained this shift as follows: "In the early stage, it was common to introduce the students and their names in public on the school webpage. Then came the privacy protection issues, and we got more cautious."

Some principal informants reported the ethical and legal issues related to online publishing challenging the school to a complex matter, where parents play an inevitably strong role. Copyright confusion (Hobbs et al., 2009), privacy laws, and the fear that adolescents will disclose personal matters unintentionally (Tuominen \& Mustonen, 2007) have made schools cautious, especially since parents tend to intervene in the school's operations more easily than before. Principal 1 commented on this situation as follows: "In the past years, parents and society have been constantly seeking for an appropriate degree of interfering and criticizing. That's why we have become so cautious. We willingly think that nothing happens if we don't specially do anything."

In the riptide of parental control, few schools presented an active sharing strategy for the videos. School work was distributed using online platforms with restricted accessibility or embedded in YouTube or in informal blogs - a way of indirect publishing. Some teacher informants claimed that the videos displayed on the school homepage connected the students with the school. Online publishing was considered more legitimate on webpages other than the official school homepage, which was regarded as a place for more formal information.

These kinds of opinions show that educators consider the networked media Janus-faced. All interviewed parents took a positive stance toward DV production and online publishing, similar to many teachers and principals. However, the latter found it somewhat difficult to allow online activities at school, due to legislation and recently increased parental control. 
Most interviewed students were active video publishers in their leisure time. The boys produced and shared videos on computer gaming, skateboarding, and other forms of physical exercise, whereas the girls shared their videos mostly in blogs related to hobby horsing or, for secondary-level students, fashion or lifestyle. Blogging, especially on lifestyle, is common among Finnish secondary-level girls (Kupiainen, 2013a).

According to the teachers and principals, the primary students show enthusiasm about writing plays, acting, shooting videos, and online publishing to show their videos to people other than their

peers and parents. However, the learners' reluctance to act and perform in school-based videos and publish them on school-context online television increases with age. This perception was supported by both the observations of and interviews with students of different ages, as well as the study of Buckingham and colleagues (2011). Referring to an inspiring effect on the learners, though weakening with age, this finding about online publishing for an authentic public is consistent with the results of Karchmer (2008). Accordingly, an observation of sChOOLtv revealed that few videos produced by secondary students had been published there.

\section{To publish or not to publish}

The decision to publish was made primarily by the students and parents, who granted permission to sChOOLtv activities. Although they listened to their children's opinions, all interviewed parents considered themselves responsible for the final decision. The teacher informants relied on the parents' decisions. Nevertheless, in many schools, electronic permission was missed or neglected by the parents. Furthermore, some teachers and principals reported that some parents, presumably those with no experience in networked environments, refused to give permission due to excessive worry about online risks. Such parents were said to ignore lectures on media education organized in connection with parent events. Consequently, refusing to give permission hindered the publishing-oriented video projects:

Parents denying the sChOOLtv permission generate problems for the teachers on how to organize alternative learning activities. Is it ethically right to produce formats in which not all are allowed to participate? We should, of course, give equal education to everyone... When a video movie is filmed, everyone wants to be involved, but those with no permission for online publishing should be excluded. (Principal 3)

Nevertheless, the teachers expected parents to support the school's online practices. Observed Teacher 7 invited all parents to adapt to modern media: "They must understand that children should practice these issues guided at school ... to prevent the situation where an eighth grader just starts by 
publishing an embarrassing video online ...@oops@” Thus, all children could obtain the required media competencies.

Parent 2 claimed that some teachers could have inadequate skills or attitudes to implement education in online publicity: "Most teachers may by now be willing to use the computer, but not all of them can provide children with digital awareness." Teacher interviews revealed how the teachers ultimately decide whether to publish a work, based on its content or their personal preferences. Rather surprisingly, despite their active role as DV promoters, some interviewed teachers and principals took a negative stance toward the current media anxiety, criticizing the children's excessive media time. They criticized the undesirable effects of social media on the adolescents, such as provoking a narcissistic tendency, and emphasized the parents' responsibility of media monitoring at home in terms of age limits and media time restrictions. Furthermore, since they considered online publishing of videos pointless in the learning process, some interviewed teachers and principals found it sufficient to show and discuss the videos in the classroom or share them with a limited group of people: "We often share videos just on the extranet, believing that it's enough to prepare the kids for coping with online publicity" (Principal 3). They argued that the pedagogical goal of DV production could also be achieved in an environment with restricted access, such as an extranet for parents and families only. In the name of the contemporary culture of openness, these critical informants longed for sustainable negotiated practices and a system with an adjustable audience and degree of publicity.

Students, especially those at the secondary level, can complicate publishing-oriented DV production. Their teachers mentioned that many teenagers refuse to use their own voices to record a narrated digital story for formal exposure: "For some, it's hard to use and hear one's own voice ... they love to make digital stories with photos, music, and written text, but ... well, the idea of a digistory is the spoken narration ... it's told using one's own voice" (Interviewed Teacher 6). Furthermore, some secondary students avoided exposing their faces on open-access websites, fearing someone might capture the images.

Consequently, the reluctance to publish school-driven videos puzzled some teacher informants:

Let's make a comparison: Our students are posing online in all kinds of social media applications like there's no tomorrow. Then they are not willing to say something in their own voice for digital presentations when asked. I think it's totally unintelligible! If you did something similar at school that you are doing in your leisure time, you would be bullied for it and regarded as a freak. (Interviewed Teacher 5) 
Some teenage students criticized themselves as movie makers as follows: "Dunno, I think the video is quite stupid. Just messing around there" and "And it's not nice to hear your own speech either ..." It can be speculated that the adolescents might worry about a quality standard for videos that had not been set at all. Publishing videos on sChOOLtv was considered to negatively influence the students' reputation by harming their fame and street credibility among peers, which was highly prioritized by the interviewed eighth graders: "The fact that it's school work and everyone would see it, it would be embarrassing! There's like no point to publish it there.” They might also be worried about being bullied for the video or, if it were disseminated in contexts beyond the school platform, harming their carefully constituted online image.

Furthermore, various challenges made it difficult to employ online publishing and even DV production in the classroom curriculum. In secondary school, Interviewed Teacher 2 reported that this was partly due to the strict timetables, curriculum content, and goals, and thus, the textbookbased instruction to which many Finnish schools still adhere. Some teacher informants regarded DV production as burdensome, claiming technical dilemmas concerning DV equipment and software and difficulties in motivating some of their students and orchestrating the group activities. For example, Interviewed Teacher 2, who believed that the atmosphere in some classes with passive students and no exhilarating leaders did not support collaborative DV projects, speculated that "all those video projects may have palled on the kids, draining their energy." Furthermore, many of the teachers complained about the complexity of the copyright law and the limited availability of "good," free music. As students insisted on using copyrighted hit music in their videos, it was impossible to publish them.

Besides underrating the idea of online publishing of learner-generated videos, most criticisms of $s$ ChOOLtv were related to the technical aspects of using YouTube. First, its privacy settings were considered less sophisticated than those of many other social media platforms such as Facebook, where single messages can be targeted to differentiated groups. On YouTube, videos can be uploaded as unlisted or private with selected user rights and then embedded in a website with limited or open access. Second, many of the informants had misgivings, because after watching a video on the sChOOLtv channel, one could stray to the rest of YouTube, where inappropriate material might be visible (although such videos are usually removed promptly based on users' reports). Furthermore, YouTube was reported to have a bad image in the eyes of some parents and teachers due to associations with bullying videos or the recent school shootings. According to these informants, the school and students should not operate in such networked environments. It is worth noting that the 
critical attitude might have been absorbed with little personal experience in the video-sharing service. On the other hand, exposing learner-generated media content on YouTube was defended as follows:

I think it's somehow hypocritical to resist publishing on YouTube ... if YouTube couldn't be used at school, although it's one of the most popular websites, and the kids visit the site every day ... so I don't know if we at school should be saying that yikes, you must not go there! (Interviewed Teacher 3)

The sChOOLtv teachers suggested informing the young students about inappropriate materials - particularly those that may pop up on video-sharing sites — and advising them how to react in such a case.

In contrast to the teacher informants who criticized YouTube as a platform for school-context television, some of the secondary-level interviewees took a positive stance toward it. They claimed that YouTube offered the prospect of fame, which seemed to excite some teenagers who fantasized about earning money and becoming famous through YouTube, similar to Psy or the Finnish teenagers' group Justimusfilms, whose music videos are popular on YouTube.

\section{Media encouragement to enable education in online publicity}

The interviewed teachers found it difficult to identify specific practices to encourage students to publish videos online. In the classes led by the most active $s$ ChOOLtv teachers, online publishing had become a very natural continuum to DV production and all students and their parents had given sChOOLtv permission to publish the videos. The teachers regarded proper information for students and parents, i.e., what it meant to produce and publish media content online, as a way to accomplish media encouragement. They also emphasized the added value for the students and their circles: by publishing on sChOOLtv, the students can easily show their videos to their parents and peers. Additionally, they suggested that to encourage and guide a publishing-oriented, collaborative DV process with a pedagogical goal, the teacher should provide the students with a distinct framework for the assignment:

The process hardly begins with the idea of "do whatever you want"; there always has to be a clear idea about the message of the video. But the students come up with the rest ... Yet the theme and content must, of course, be eligible and appropriate for online publishing. (Interviewed Teacher 4)

Thus, some freedom should be offered to the groups in implementing the DV project, as the teachers and principals asserted that the students were especially motivated by autonomy in planning and storyboarding the DV movie. They proposed that for the older students, emphasis should be 
shifted from acting and performing to authentic themes, expressing opinions, and engaging in discussions, to encourage secondary students to take an active democratic role:

In the primary school, it's pretty easy to find stuff for publishing, because students are enormously eager to perform in front of the camera. In the secondary school, the traditional idea of performing doesn't work. I think the teacher should find... the genre that would find resonance. Themes that would be important and relevant to the youngsters, hobbies, lifestyle, future ... taking a stance ... that kind of stuff. (Principal 1)

Nevertheless, many additional practices used by the teachers to implement media encouragement were identified, including developing their own and the students' skills in media content creation, digital storytelling, and movie making, as well as developing their knowledge about online publishing, copyright, and privacy laws. A very important encouraging practice was for classmates to review and discuss the produced videos. By choosing a publishing platform for students' media content, the teachers provided the students with an authentic channel for distribution and feedback. One of the primary teachers was astonished by a student group's uninhibited willingness to expose not only their faces, but also their full names, in a publishing-oriented video. To protect the students' privacy, the teachers advised young actors to include only their nicknames or first names in the cast list and to film human figures without recognizable faces. In addition to the students and parents, the teachers also informed their colleagues about online publishing and privacy management. Furthermore, they promoted their ideas among the school staff by inviting their colleagues to conduct joint DV projects and stressing the importance of media educational discussions at home.

Among the teachers and principals, multipartite educational dialogue (Jaakkola, 2010) was considered an important practice of media encouragement, with the home as the central stakeholder of the discussion. Although some teachers described sChOOLtv as having provoked discussion among those involved about what can or cannot be shown there, the study reveals that, at home, students and their parents rarely debated on issues related to online activities and the permission collected electronically from parents. This may be because the parents have confidence in schoolcontext online activities, as stated by Parent 5: "We know that the school doesn't get involved in anything wrong or suspicious ... for sure, we'll always give permission, trusting that nobody would make anything that couldn't be published."

The statement shows that the parent informants trusted teachers to set and control appropriate ground rules and to make the learners conscious of the boundary between private and public activities. 
However, controlling students who were getting acquainted with online activities was no easy task for teachers: "Of course, informing students and homes included a promise that it's the teacher who uploads, not the kids ... that we control the content to be uploaded" (Interviewed Teacher 3). The teachers, constantly struggling between "risk taking" and "safe use," must become accustomed to unpredictable consequences such as inappropriate feedback from peers.

Yet, among most educator informants, the importance of rule negotiations was emphasized: "Openness is just good on the condition that the public activity occurs under control, and everyone knows their responsibilities and the common model of operation" (Principal 1). For this negotiation, sChOOLtv aimed to provide a potential forum for the teachers and principals, parents, and students with their peers.

\section{Discussion}

This article aimed to examine the participants' views on online publishing of learnergenerated videos and discuss ways to promote publishing-oriented DV production in schools. It also discussed the school's relationship with publicity within media education through the case study on the online television sChOOLtv. Authentic activities, particularly learner-generated online videos, in a safe, guided, and controlled networked environment for learning were expected to involve all parties in negotiating the ground rules (Jaakkola, 2010; Laitinen, 2007). Although online publicity is rarely totally safe and controllable, and the term "guided" is slightly misleading in terms of the learners' agency, authorship, and autonomy (Jaakkola, 2010), sChOOLtv, despite its shortcomings, can be acknowledged to enhance new literacies and promote participatory culture. First, the teachers who created sChOOLtv and those who participated in the teacher network discussed the issues related to online publishing. Second, the meaning and operating principles of sChOOLtv were discussed with the parents, which enhanced the partnership between the school and the home. Third, the students who shared the joint publishing-oriented DV production were able to consult with their peers and teachers. As the involved parties negotiated and collaboratively improved the ground rules of publicity around $s$ ChOOLtv, they promoted education in online publicity from the sociocultural perspective.

Nevertheless, discussions on $s$ ChOOLtv permission or media use between students and their parents were scarce. Furthermore, sChOOLtv does not seem to completely fulfill sharing as an act of social exchange, i.e., online communication about videos among users. Many comments on the sChOOLtv videos were removed due to their inappropriateness not to discourage the young 
producers. Since joint review events of videos on YouTube are prohibited by the current Finnish copyright law (Toikkanen \& Oksanen, 2011), it is difficult to learn and practice how to give feedback. Moreover, the age limits prevent primary-level students from commenting on YouTube videos. This study suggests a need to teach students, through serious classroom discussions, how to give feedback in a constructive manner and how to receive and process inappropriate comments.

For schools, learner-generated videos published online are seen as a mode of PR and a showcase of the school's activities for parents and other stakeholders. Although they recognize the Janus-faced nature of youth online activities, most educators seem to have adapted to the presence of online media in the children's everyday lives and acknowledged the need for education in online publicity, namely, how to construct an online image safely. This field is a matter of educational discussion and a subject for negotiating the shared rules of online behavior. The publishing-oriented DV production is considered a trustworthy and meaningful environment for becoming acquainted with online publicity, though the parents emphasize the school's controlling role in uploading the video materials on $s$ ChOOLtv. As a literacy practice, the activity has many benefits in terms of communicative and participatory competencies related to technical, critical, creative, and ethical practices (Kafai \& Peppler, 2011), which prepare children for the future.

The attitudes of teachers, parents, and students may hinder online publishing of learnergenerated videos. Both parents and teachers can take the crucial role of gatekeeper in online publishing: parents can do so by granting or withdrawing sChOOLtv permission, whereas teachers can do so by employing or neglecting publishing-oriented DV production and ultimately deciding whether to publish a video based on its content or their personal preferences. The teacher oscillates between the roles of a promoter and a protector, either nurturing a positive attitude toward openness and sharing or restricting the learners from the networked public and communication. From the perspective of professional development, teachers can be reluctant to employ online publishing in a classroom curriculum because they worry that networked activities could threaten their expertise and control.

The study detects several forms of inequality in media education, such as the division of children into those with and without sChOOLtv permission, which excludes some from DV production. Furthermore, not all parents are familiar with social media; thus, many homes are still unable to educate children in online publicity. This situation is alarming, since children need guidance to grow independent in the media, with its commercial nature and other invisible minuses (Buckingham, 2006). Parents with more critical attitudes should also understand that online practices 
at school are preferred to one's own when publishing videos that might violate privacy or copyright laws.

In addition to increased self-criticism that teenagers tend to face (Buckingham et al., 2011), other perspectives on their reluctance to engage in publishing-oriented DV production in the school context should be considered. Gibbons (2013) suggested that presenting one's identity in networked media is challenging for young people. Adolescents who are conscious of their developing web image (Kupiainen, 2013a) may become more reluctant, afraid of receiving nasty comments, being bullied, and losing their credibility among their peers. Furthermore, they might consider online publishing as a context that they want to leave as an option for themselves, probably due to a perceived feeling of control or power relations. Kupiainen (2013a) considered teenagers to be entitled to their own privacy in relation to their parents; likewise, it can be speculated that they do not want the school to enter their "media territory" (Ito, 2010). Thus, the power relations between the school and the youth media culture may be one of the factors keeping secondary-level students from producing and publishing media content at school.

Because of the monomodal individual texts used in the Finnish classroom curriculum (Luukka et al., 2008), it is worth considering whether students learn by the secondary level that texts produced at school are internal and rarely authentic. The students need to become conscious of the emerging active membership in online communities, enhancing the ideology of sharing and collaborating in such settings. The publicity of schools has advanced due to communication technology, current trends, and active partnership with parents. Nonetheless, the promotion of online presence seems to be restrained in some schools due to the educators' trepidations resulting from negative phenomena such as cyber bullying and virtual abuse of children (Livingstone et al., 2011). It is sad to find that the culture of openness and sharing emerging in the field of education, through learning resources constructed collaboratively and shared with other users, may still be just rhetoric for many schools.

Various publicity policies exist in the case schools in terms of online publishing of learnergenerated videos: publishing videos on sChOOLtv, publishing indirectly in non-indexed blogs, or, partly due to increased parental control, publishing on an extranet application with restricted access or no online publication. However, none of the schools fully obeyed a specific policy; rather, the choice was determined by individual teachers, who may promote school-context online publishing in various ways identified by this study. Permission for school-context online publishing can be promoted by increasing the parents' and students' awareness of these issues. As children may not realize how broadly and quickly online content is disseminated and what its consequences are (Tuominen \& Mustonen, 2007), media encouragement also involves protecting the students' privacy 
by advising young actors in terms of protecting their names and images. To enhance students' motivation, they should be provided with non-private themes, though challenging, age-appropriate video tasks. Furthermore, to promote publishing-oriented learner-generated DV production, the schedule and curriculum, as well as technical and ethical issues (Buckingham et al., 2011) restricting DV production should be managed.

The study presents a media educational paradox: the older students who would benefit most from education in online publicity have lost their willingness to participate in this kind of actionbased media education, whereas primary-level students who want to publish are too young to sign up on social media platforms. Thus, education in online publicity should be started no later than at the age of 10 or 11 , when the student's online image has not yet been constructed or a mental threshold has not yet arisen. It should be guided and controlled by teachers (Laitinen, 2007), allowing the level of encouragement to grow along with age, based on a deepened understanding of the public (Herkman, 2007; Jaakkola, 2010).

To evaluate the study, limitations in the preparation, organization, analysis, and reporting phases of the study were considered (Elo et al., 2014). Due to the case study approach (Yin, 2009), many types of triangulation (data, methods, and investigators) (Denzin, 1970/2009) are involved. As the study focused on sChOOLtv and its online activities, most informants had a positive attitude toward publishing-oriented DV production. This was especially true for the interviewed parents, since no parents with critical attitudes, possibly due to scarce experience in social media, volunteered for the study. To reduce the educator bias, the teachers who did not participate in the sChOOLtv activities were recruited as informants to capture various perspectives on online publishing. The students also offered more diverse opinions. Due to the study's explorative, temporal, and situational nature, the reported results cannot be generalized but concern only the reported circumstances and informants.

\section{Conclusion}

The article introduced an emerging research area that is important not only for the educators but also for the youth. This study recommends the addition of publishing-oriented DV production to the classroom curriculum in primary and secondary schools, since it affords many benefits related to the culture of openness and to students' emotions, identity, motivation, and literacy (Buckingham et al., 2011). The study also stresses the need to construct the pedagogy for education in online publicity to help us invite the students, parents, and teachers to negotiate and improve media ground rules with practical and ethical guidelines. 
Based on the media encouragement described in this article, the pedagogy could be constructed on a school-context video channel such as $s$ ChOOLtv, where students can publish their videos and practice their relationship with authentic publicity before entering it on their own. The responsibilities and legal aspects need to be discussed by all involved parties to ensure that the students become aware of these issues and to protect them from missteps. Although the school is the key agent in coordinating the multilateral discussion among all involved parties, education in online publicity is also part of the parents' educational responsibilities. Additionally, the instructions and permission practices need to be standardized. The pedagogy should proceed from the mere decision of whether "to publish or not" to considering multifaceted aspects related to publicity.

Online publishing calls for in-depth theoretical conceptualizations and further examination of practices related to publishing-oriented DV production. However, media education as a research focus is continuously transforming, which may complicate the conceptualization and render the results obsolete. The media gap between the generations (youth and educators or researchers) is a challenge to education (Jenkins et al., 2006; Jaakkola, 2010) and related research affecting the researchers' thinking and reflecting (Weber \& Mitchell, 2008). To manage this challenge, future studies should be developed in collaboration with the youth. The students who piloted online publishing on sChOOLtv should also be interviewed. Now at the secondary level, they can bring valuable insights on their experiences and their attitudes toward online publicity. Finally, this study suggests the need to examine and improve the students' online feedback.

\section{References}

Ackermann, E. K. (2011). Minds in Motion, Media in Transition: Growing up in the digital age: Areas of change. Child Research Net 1/2011. Retrieved from

http://www.childresearch.net/papers/digital/2011_01.html

Bailey, B. (2009). Reel literacies: Digital video production as a literacy practice (Doctoral dissertation). Rochester, NY: University of Rochester.

Bobbio, N. (1989). Democracy and dictatorship. Minneapolis: University of Minnesota Press.

Boyd, D. (2008). Why youth (heart) social network sites: The role of networked publics in teenage social life. In D. Buckingham (Ed.), Youth, identity, and digital media (pp. 119-143). Cambridge: MIT Press.

Buckingham, D. (2006). Defining digital literacy: What do young people need to know about digital media? Nordic Journal of Digital Literacy 4(1), 263-276.

Buckingham, D., Willett, R., \& Pini, M. (2011). Home truths? Video production and domestic life. Michigan, MI: Ann Arbor. 
Butler, D., Leahy, M., \& McCormack, C. (2010). Redefining book reviews for the digital age. Contemporary issues in technology and teacher education, 10(1), 80-99. Retrieved from

http://www.citejournal.org/vol10/iss1/languagearts/article4.cfm

Coiro, J., Knobel, M., Lankshear, C., \& Leu, D.J. (Eds). (2008). Handbook of research on new literacies. Mahwah, NJ: Erlbaum.

Denzin, N. K. (2009). The research act: A theoretical introduction to sociological methods. Chicago, IL:

Aldine. (Original work published 1970)

Elo, S., Kääriäinen, M, Kanste, O., Pölkki, T., Utriainen, K., \& Kyngäs, H. (2014). Qualitative content analysis: A focus on trustworthiness. SAGE Open. January-March 2014, 1- 10.

Gee, J. P. (2010). New digital media and learning as an emerging area and "worked examples" as on way forward. Cambridge, MA: MIT Press.

Gibbons, D. (2013). Developing an ethics of youth media production using media literacy, identity, \& modality. Journal of Media Literacy Education, 4(3), article 6. Retrieved from http://digitalcommons.uri.edu/jmle/vol4/iss $3 / 6$

Glaser, B. G. \& Strauss, A. L. (1967). The discovery of grounded theory: Strategies for qualitative research. New York, NY: Aldine de Gruyter.

Hakkarainen, P. (2007). Promoting meaningful learning through the integrated use of digital videos (Doctoral dissertation). Rovaniemi, Finland: University of Lapland.

Herkman, J. (2007). Kriittinen mediakasvatus [Critical media education]. Tampere: Vastapaino.

Hobbs, R. (2011). The state of media literacy: A response to Potter. Journal of Broadcasting \& Electronic Media 55(3), 419-430.

Hobbs, R. \& Donnelly, K. (2011) Toward a pedagogy of fair use for multimedia composition. In M. Courant Rife, S. Slattery, \& D. N. DeVoss (Eds.) Copy(write): Intellectual property in the writing classroom (pp. 275-294). West Lafayette, IN: Parlor Press.

Hobbs, R., Jaszi, P., \& Aufderheide, P. (2009). How media literacy educators reclaimed copyright and fair use. International Journal of Learning and Media 1(3), 33-48. http://dx.doi.org/10.1162/ijlm_a_00026.

Ito, M. (2010). Peer-based learning in a networked age [Web log post]. Retrieved from http://www.itofisher.com/mito/publications/peerbased_learn_2.html Jaakkola, M. (2010). Uuden julkisuuden sääntöjä luomassa: Keskustelevat vuorovaikutussuhteet keinona sukupolvien välisen digitaalisen kuilun kaventamiseen. [Creating ground rules for the new publicity: Dialogical relationships as a method to bridge the digital gap between the generations], in M. Meriranta (Ed.), Mediakasvatuksen käsikirja [Handbook of media education] (pp. 37-62). Helsinki: Unipress. Jenkins, H., Clinton, K., Purushatma, R., Robison, A., \& Weigel, M. (2006). Confronting the challenges of a participatory culture: Media education for the 21st century. Chicago, IL: MacArthur Foundation. Retrieved from http://files.eric.ed.gov/fulltext/ED536086.pdf 
John, N. A. (2012). Some of the social logics of sharing. In W. Sützl, F. Stalder, R. Maier, \& T. Hug (Eds.), Media, knowledge, and education: Cultures and ethics of sharing, (pp. 45-58). Innsbruck: Innsbruck University Press.

Kafai, Y. B. \& Peppler, K.A. (2011). Youth, Technology, and DIY: Developing Participatory Competencies. Creative Media Production Review of Research in Education, 35 (1), 89-119.

Karchmer, R. (2008). The journey ahead: Thirteen teachers report how the Internet influences literacy and literacy instruction in their K-12 classrooms. In J. Coiro, M. Knobel, C. Lankshear, \& D. Leu (Eds.), Handbook of research on new literacies (pp. 1241-1280). New York, NY: Erlbaum Associates.

Kearney, M. (2009). Towards a learning design for student-generated digital storytelling. The Future of Learning Design Conference. Paper 4. Retrieved from http://ro.uow.edu.au/fld/09/Program/4 Kupiainen, R. (2013a). Young people's creative online practices in the context of school community. Cyberpsychology: Journal of Psychosocial Research on Cyberspace, 7(1), article 8. doi:10.5817/CP2013-1-8 Kupiainen, R. (2013b). Media and digital literacies in secondary school. New York, NY: Peter Lang. Laitinen, S. (2007). Kuvaa ymmärtämään: visuaalisen mediatajun ja -taidon opettamisesta [To understand pictures: thoughts about visual media comprehension and skills]. In H. Kynäslahti, R. Kupiainen \& M. Lehtonen (Eds.), Näkökulmia mediakasvatukseen [Perspectives on Media Education] (pp. 61-72). Helsinki: Mediakasvatusseura. Retrieved from http://www.mediakasvatus.fi/publications/ISBN978-952-99964-14.pdf.

Lange, P. G. \& Ito, M. (2010). Creative production. In M. Ito, S. Baumer, M. Bittanti, D. Boyd, R. Cody, B. Herr-Stephenson, H.A. Horst, P.G. Lange, D. Mahendran, K. Martinez, C.J. Pascoe, D., Perkel, L. Robinson, C. Sims, L. Tripp (Eds.), Hanging out, messing around, and geeking out (pp. 243-293). Cambridge, MA: MIT Press.

Lehtonen, J. (2008). Risks and crises in virtual publicity: Can publicity crises be prevented by public relations in cyberspace. In: Zerfass, A. \& B. vanRuler \& K. Shiramesh (Eds.), Public Relations Research: European and International Perspectives and Innovations (pp. 305-312).Wiesbaden: VS Verlag. Lenhart, A. (2012). Teens \& Online Video: Shooting, sharing, streaming and chatting: Social media using teens are the most enthusiastic users of many online video capabilities. Retrieved from http://www.pewinternet.org/ /media//Files/Reports/2012/PIP_Teens_and_online_video.pdf. Livingstone, S., Haddon, L., Görzig, A., \& Ólafsson, K. (2011). EU Kids Online: Final report 2011. London, UK: EU Kids Online Network. Retrieved from http://eprints.lse.ac.uk/45490/ Luukka, M.R., Pöyhönen, S., Huhta, A., Taalas, P., Tarnanen, M., \& Keränen, A. (2008). Maailma mииttuи—mitä tekee koulu? [The world changes—what does the school?]. Centre for Applied Language Studies. Jyväskylä, Finland: University of Jyväskylä.

Malin, B. J. (2011). A very popular blog: The Internet and the possibilities of publicity. New media \& society, 13(2), 187-202. doi: 10.1177/1461444810369889

National Board of Education. (2004). Perusopetuksen opetussuunnitelman perusteet 2004 [National Core Curriculum for Basic Education 2004]. Helsinki, Finland: National Board of Education. 
Nieminen, H. (2006). Kansa seisoi loitompana: Kansallisen julkisuuden rakentuminen Suomessa 1809-1917 [The people stood further: Constructing the national publicity in Finland]. Tampere: Vastapaino.

Palmgren-Neuvonen, L., Kumpulainen, K. [Kari], \& Vehkaperä, A. (2011). Oppimisen taitoja liikkuvalla kuvalla: Teknologioiden innovatiivista yhdistelyä äidinkielen opetuksessa [Acquiring learning skills by producing moving images], in Kankaanranta, M. (Ed.) Opetusteknologia koulun arjessa [Educational technology in school's everyday life] (pp. 189-207). Jyväskylä: University of Jyväskylä, Finnish Institute for Educational Research.

Pohjola, K., \& Johnson, E. (2009). Lasten mediakulttuuri ja koulu vuoropuheluun [Promoting the dialogue between the children's media culture and the school]. Jyväskylä: University of Jyväskylä, Finnish Institute for Educational Research.

Potter, J. (2010). The state of media literacy. Journal of Broadcasting and Electronic Media, 54(4), 675-696. Rogers, E. M. (2003). Diffusion of innovations. $5^{\text {th }}$ edition. Free Press, New York.

Stern, S. (2008). Producing Sites, exploring identities: Youth online authorship. In D. Buckingham (Ed.), Youth, identity, and digital media (pp. 95-117). Cambridge: MIT Press.

doi:10.1162/dmal.9780262524834.001

Suoninen, A. (2013). Lasten mediabarometri 2012. 10-12-vuotiaiden tyttöjen ja poikien mediankäyttö

[Children's media barometer 2012: The Use of Media among 10-12-year-olds in Finland]. Helsinki:

Nuorisotutkimusverkosto.

Toikkanen, T. \& Oksanen, V. (2011). Opettajan tekijänoikeusopas [The handbook of copyright for teachers]. Helsinki: Oy Finn Lectura Ab, 2011. ISBN 978-951-792-468-9.

Tuominen, S. \& Mustonen, A. (2007). Tunteella ja järjellä nettiin: Internetissä tarvitaan uudenlaisia mediataitoja. [With emotion and common sense in the Net] In H. Kynäslahti, R. Kupiainen, \& M. Lehtonen (Eds.), Näkökulmia mediakasvatukseen [Perspectives on Media Education] (pp. 137-150). Helsinki: Mediakasvatusseura. Retrieved from http://www.mediakasvatus.fi/publications/ISBN978-952-99964-14.pdf.

Uusitalo, N., Vehmas, S., \& Kupiainen, R. (2011). Naamatusten verkossa: Lasten ja nuorten mediaympäristön muutos, osa 2 [Face-to-face in the Net: The changing adolescents' media environments, Vol. 2]. Tampere: University of Tampere.

Vahtivuori-Hänninen, S. \& Kynäslahti, H. (2012). ICTs in a school's everyday life. In H. Niemi, A. Toom \& A. Kallioniemi (Eds.), Miracle of education: The principles and practices of teaching and learning in Finnish schools (pp. 237-248). Rotterdam: Sense Publishers.

Weber, S. \& Mitchell, C. (2008). Imagining, keyboarding, and posting identities: Young People and new media technologies. In D. Buckingham (Ed.), Youth, identity, and digital media (pp. 25-48). Cambridge: MIT Press.

Wittel, A. (2011). Qualities of sharing and their transformations in the digital age. International Review of Information Ethics, 15(09), 3-8.

Yin, R. K. (2009). Case Study Research: Design and Methods. Thousand Oaks, CA: Sage. 
Ylä-Kotola, M. \& Arai, M. (2000). Uusmediatieteen perusteet [Basics of the new media sciences]. Helsinki: Edita.

\section{Appendix}

Table A1

Examples from Open Coding to Categories

[Insert Table A1 here] 